Scientia Agricola

http://dx.doi.org/10.1590/1678-992X-2015-0284

\title{
Parametrization of the Davis Growth Model using data of crossbred Zebu cattle
}

Adriele Giaretta Biase ${ }^{1}$, Carlos Tadeu dos Santos Dias ${ }^{1 *}$, Luís Gustavo Barioni², Tiago Zanett Albertini ${ }^{3}$, Lucieta Guerreiro

Martorano ${ }^{4}$, James W. Oltjen ${ }^{5}$, Dante Pazzanese Duarte Lanna ${ }^{3}$, Patrícia Perondi Anchão Oliveira ${ }^{6}$, Sérgio Raposo de Medeiros ${ }^{7}$, Roberto Augusto de Almeida Torres Júnior ${ }^{7}$

${ }^{1}$ University of São Paulo/ESALQ - Dept. of Exact Sciences, C.P. 09 - 13418-900 - Piracicaba, SP - Brazil.

2Embrapa Agricultural Informatics, Av. André Tosello, 209 Campinas, SP - Brazil.

3University of São Paulo/ESALQ - Dept. of Animal Sciences.

${ }^{4}$ Embrapa Eastern Amazon, Trav. Dr. Enéas Pinheiro, s/n

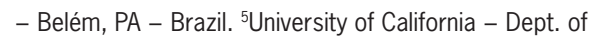

Animal Science, One Shield Av., P.O. Box 95616 - Davis,

CA - USA.

${ }^{6}$ Embrapa Southeast Livestock, Rod. Washington Luiz, km

234 - São Carlos, SP - Brazil.

'Embrapa Beef Cattle, Av. Rádio Maia, 830 - Campo

Grande, MS - Brazil.

*Corresponding author <ctsdias@usp.br>

Edited by: Thomas Kumke

Received July 14, 2015

Accepted April 26, 2016
ABSTRACT: The system of differential equations proposed by Oltjen et al. [1986, named Davis Growth Model (DGM)] to represent cattle growth has been parameterized with data from Bos taurus (British) and Bos indicus (Nellore) breeds. The DGM has been successfully used for simulation and decision support in the United States. However, the effect of about 30 years of genetic improvement and the use of different breeds may affect the model parameter values, which also may need to be re-estimated for crossbred animals. The aim of this study was to estimate parameter values and confidence intervals for the DGM with growth and body composition data from Zebu crossbred animals. Confidence intervals and asymptotic distribution were generated through nonparametric bootstrap with data from a field experiment conducted in Brazil. The parameters showed normal probability distribution for most scenarios. The rate constant for deoxyribonucleic acid (DNA) synthesis had a minimum increase of $156 \%$ and the maximum of 389 $\%$, compared to the original values and the maintenance requirement had a minimum increase of $126 \%$ and maximum of $160 \%$ compared to the original values. Lower limits of $95 \%$ confidence intervals for the parameters related to maintenance and protein accretion rates were higher than the original estimates of the DGM, evidencing genetic differences of the Zebu crossbred animals in relation to the original DGM parameters.

Keywords: asymptotic distribution, calibrating, cattle growth, nonparametric bootstrap, ordinary differential equations

\section{Introduction}

Non-linear growth functions (e.g., Bhowmick \& Bhattacharya, Gompertz, Logistic, Von Bertalanffy, Weibull and Richards), with parameters estimated by regression, describe animal growth (Bhowmick and Bhattacharya, 2014; Chizzotti et al., 2008; Forni et al., 2009; Freetly et al., 2011; Marinho et al., 2013; Nesetrilová, 2005). However, they have limited capacity to estimate body composition (i.e., fat and protein), thus, neglecting the possible interactions between metabolism and composition of gain dynamics (NRC, 1996).

Mathematical models for beef cattle growth by France et al. (1987), Hoch and Agabriel (2004), Oltjen et al. (1986), Tedeschi et al. (2004), Williams and Bennett (1995) and Williams and Jenkins (2003) are potentially more useful than the models mentioned in the previous paragraph, as they express variables including metabolism and nutrient availability. The model described by Oltjen et al. (1986), named Davis Growth Model (DGM), and updated by Oltjen et al. (2000) was chosen for this study because it is one of the most parsimonious, interpretable and easy for computational implementations.

Although there are several studies on nutritional requirements of cattle in Brazil (Marcondes et al., 2010a, b; Paulino et al., 2010; Sainz et al., 2006; Valente et al., 2013), the DGM parameterization for Zebu genetics explored under Brazilian conditions has never included the estimation of parameter distribution by nonparametric bootstrap and statistical inferences.
In this context, this study aimed to calibrate parameters of the DGM to adapt it to the British (Bos taurus) $\times$ Zebu (Bos indicus) crossbred genotypes, to study the asymptotic distribution of the parameters of the mathematical model based on a nonparametric bootstrap method, and to estimate the confidence intervals for these parameters.

\section{Materials and Methods}

The methods are described in three subsections: Data, describing the experiment; Model, with a detailed description of variables and parameters from the DGM; Computational Statistics, which describes the procedures of algorithms to solve Ordinary Differential Equations (ODE), objective function optimization methods, and nonparametric bootstrap.

\section{Data}

Data for parameter estimation was obtained from a trial conducted in Campo Grande, Mato Grosso do Sul (MS) State, Brazil $\left(20^{\circ} 26^{\prime} 39^{\prime \prime} \mathrm{S}, 54^{\circ} 43^{\prime} 24,6^{\prime \prime} \mathrm{W}\right.$ and altitude of $500.25 \mathrm{~m}$ ), in 2007. All procedures with animals were conducted according to the Embrapa Beef Cattle and University of São Paulo ethical standards established by the College of Agriculture Commission. The data comprised 27 crossbred cattle $1 / 2$ Red Angus $\times$ $1 / 4$ Caracu $\times 1 / 4$ Nellore $[R C N, n=8$ female $(F)$ and 10 young bulls $(\mathrm{M})]$ and Red Angus $\times$ Nellore $(\mathrm{RN}, \mathrm{n}=5$ $\mathrm{F}$ and $4 \mathrm{M})$. Before weaning, the animals were raised in 
two systems: pasture system (PS) and confined system (CS). In PS, cows and their calves (cow-calf pairs) were kept on pasture with a mineral supplement (15\% Na, 11 \% Ca, 9 \% P, 1 \% Mg, 7 \% S, 6.691 ppm Zn, 2.829 ppm Fe, 1.153 ppm Cu, 797 ppm Mn, 90 ppm I, 31 ppm S and 24 ppm Co, dry matter basis). Intake and body composition of cow-calf pairs were not evaluated in the PS. In the CS, calves were fed with the same diet [2.3 Mcal ME $\mathrm{kg}^{-1}$ dry matter (DM) basis, $13 \%$ crude protein $\left.(\mathrm{CP})\right]$ with cows on an ad libitum basis from 33 days of age until weaning. The DM intake of each cow was adjusted individually in 28-day intervals to minimize change in body weight (BW) and to keep Body Condition Scores (BCS) constant [diet and management are presented in detail in Albertini et al. (2012)]. After weaning (225 \pm 14 days), animals from both systems were individually fed a total mixed diet (2.84 Mcal ME kg-1 DM, $14 \% \mathrm{CP}$, $\mathrm{DM}$ basis) in individual stalls. Animals were slaughtered when they reached $6 \mathrm{~mm}$ of subcutaneous fat in the 12 $13^{\text {th }}$ ribs (feedlot maximum period was 147 days).

At the beginning of the feedlot period, the initial chemical body composition was derived from the slaughter of two to four animals of each genotype. In addition, at the end of feedlot period, animals were slaughtered and retained energy was estimated based on the composition of the $9-10-11^{\text {th }}$ ribs.

Empty body chemical composition was estimated from linear regressions of percentage of water and fat in the $9-10-11^{\text {th }}$ ribs. The original Hankins and Howe (1946) methodology was modified, so that the entire rib sections (bones and soft tissue) were ground. The composition of the entire 9-10-11 ${ }^{\text {th }}$ ribs was used. Protein and ash in the empty body were calculated from the estimated fat and water using the 80:20 ratio of protein and ash in the fat-free DM (Bonilha et al., 2011; Reid et al., 1955). The energy concentration used for protein and fat was 5.497 and $9.390 \mathrm{Mcal} \mathrm{kg}^{-1}$ of Empty Body Weight (EBW), respectively.

The variables used to parameterize the DGM were based on the information collected in the postweaning period: gender, genetic group, age, production system, initial body weight $\left(\mathrm{BW}_{\mathrm{i}}\right), \mathrm{kg}$; feedlot period (FP), d; DMI: dry matter intake (DMI), kg DMI d ${ }^{-1}$; initial shrunk body weight $\left(\mathrm{BWj}_{\mathrm{i}}\right), \mathrm{kg}$; final shrunk body weight $\left(\mathrm{BWj}_{\mathrm{f}}\right), \mathrm{kg}$; initial empty body weight $\left(\mathrm{BWz}_{\mathrm{j}}\right)$, $\mathrm{kg}$; final empty body weight $\left(\mathrm{BWz}_{\mathrm{f}}\right), \mathrm{kg}$; initial protein body weight (PROT_BWz I $_{\mathrm{i}}, \mathrm{kg}$; initial fat body weight (FAT_BWz $), \mathrm{kg}$; final protein body weight (PROT_BWz), $\mathrm{kg}$; final fat body weight $\left(\mathrm{FAT}_{\mathrm{B}} \mathrm{BW} \mathrm{z}_{\mathrm{f}}\right), \mathrm{kg}$. The aggregated dataset is summarized in Tables 1 and 2 .

\section{Model}

The DGM contains three state variables corresponding to deoxyribonucleic acid (DNA) mass, protein mass (PROT) and fat mass (FAT) totals. The DGM was originally proposed by Oltjen et al. (1986) and updated by Oltjen et al. (2000). The proposal for this model is based on concepts of hyperplasia and hypertrophy of the
Table 1 - Summary descriptive analysis [mean, standard deviation (SD), minimum (Min) and maximum (Max)] of the model input variables for 13 crossbred females.

\begin{tabular}{|c|c|c|c|c|c|}
\hline \multirow{2}{*}{$\begin{array}{l}\text { Previous } \\
\text { weaning system }\end{array}$} & \multicolumn{5}{|c|}{ Measurements after experimental weaning } \\
\hline & $\begin{array}{c}\text { Descriptive } \\
\text { measures }\end{array}$ & Mean & SD & Min & Max \\
\hline & $\mathrm{BW}_{\mathrm{i}}^{3}, \mathrm{~kg}$ & 293.75 & 25.33 & 267.00 & 328.00 \\
\hline & $F P^{4}, d$ & 90.00 & 50.95 & 47.00 & 147.00 \\
\hline & $\mathrm{DMl}^{5}, \mathrm{~kg} \mathrm{DMl} \mathrm{d}^{-1}$ & 7.40 & 1.12 & 6.35 & 8.99 \\
\hline & $\mathrm{BWj}_{\mathrm{f}}^{6}, \mathrm{~kg}$ & 386.00 & 27.60 & 347.00 & 412.00 \\
\hline \multirow[t]{10}{*}{ PS $^{1}$} & $\mathrm{BWz} z_{\mathrm{i}}^{7}, \mathrm{~kg}$ & 259.75 & 22.40 & 236.00 & 290.00 \\
\hline & $\mathrm{BWz}_{\mathrm{f}}^{8}, \mathrm{~kg}$ & 348.50 & 23.72 & 315.00 & 371.00 \\
\hline & PROT_BWz ${ }_{i}^{9}, \mathrm{~kg}$ & 44.47 & 3.86 & 40.40 & 49.70 \\
\hline & FAT_BWzi1 ${ }^{10}, \mathrm{~kg}$ & 46.30 & 3.99 & 42.10 & 51.70 \\
\hline & PROT_BWz ${ }_{f}^{11}, \mathrm{~kg}$ & 58.05 & 3.70 & 53.00 & 61.90 \\
\hline & FAT_BWz $z_{f}^{12}, \mathrm{~kg}$ & 74.40 & 7.33 & 63.40 & 78.30 \\
\hline & $\mathrm{BW}_{\mathrm{i}}, \mathrm{kg}$ & 282.22 & 24.46 & 236.00 & 308.00 \\
\hline & $\mathrm{FP}, \mathrm{d}$ & 70.11 & 22.57 & 47.00 & 119.00 \\
\hline & $\mathrm{DMl}, \mathrm{kg} \mathrm{DMl} \mathrm{d}^{-1}$ & 7.69 & 0.86 & 6.21 & 9.15 \\
\hline & $B W_{f}, k g$ & 368.33 & 25.56 & 323.00 & 413.00 \\
\hline \multirow[t]{6}{*}{$\mathrm{CS}^{2}$} & $B W z_{i}, k g$ & 249.33 & 21.60 & 209.00 & 272.00 \\
\hline & $B W z_{f}, k g$ & 328.77 & 25.84 & 286.00 & 370.00 \\
\hline & PROT_BWz, kg & 42.51 & 3.75 & 35.70 & 46.60 \\
\hline & FAT_BWz, $\mathrm{kg}$ & 46.11 & 3.92 & 37.20 & 49.90 \\
\hline & PROT_BWz, $\mathrm{kg}$ & 54.87 & 4.70 & 47.40 & 62.00 \\
\hline & FAT_BWz, kg & 69.38 & 4.79 & 62.60 & 75.80 \\
\hline
\end{tabular}

1PS: Pasture System ( $n=4$ RCN); ${ }^{2}$ CS: Confined System $(n=4$ RCN; $n=$ $5 \mathrm{RN}$ ); ${ }^{3} \mathrm{BW}_{\mathrm{i}}$ : initial body weight, kg; ${ }^{4} \mathrm{FP}$ : feedlot period, d; ${ }^{5} \mathrm{DMl}$ : dry matter intake, $\mathrm{kg} \mathrm{DMI} \mathrm{d}^{-1}$; ${ }^{6} \mathrm{BWj}$ : final shrunk body weight, $\mathrm{kg}^{7}{ }^{7} \mathrm{BWz}$ : initial empty body weight, $\mathrm{kg}$; ${ }^{8} \mathrm{BWz}$ : final empty body weight, $\mathrm{kg}$; ${ }^{9} \mathrm{PROT} \mathrm{BWz}$ : initial protein body weight, kg; ${ }^{0} \mathrm{FAT} \_B W z_{i}$ : initial fat body weight, $\mathrm{kg}$; ${ }^{11} \mathrm{PROT} \mathrm{BWz}_{\mathrm{f}}$ : final

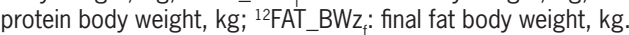

animal, described by the following set of ODE:

$$
\left\{\begin{array}{c}
\frac{\partial D N A}{\partial t}\left(g d^{-1}\right)=k_{1}\left(D N A_{\max }-D N A\right) N U T_{1} \\
\frac{\partial P R O T}{\partial t}\left(k g d^{-1}\right)=N U T_{2} k_{2} D N A^{0.73}-k_{3} P R O T^{0.73} \\
\frac{\partial F A T}{\partial t}\left(k g d^{-1}\right)=\frac{\left(\frac{M E I-M E_{M A I N T}}{N E_{m}}\right) N E_{g}-\frac{\partial P R O T}{\partial t} E P r o t}{E F a t}
\end{array}\right.
$$

where $k_{1}$ is the rate constant for DNA synthesis; $k_{2}$ is the rate constant for protein synthesis; $k_{3}$ is the rate constant for protein degradation; $D N A_{\text {max }}$ is the maximum quantity of DNA in the whole body; PROT is the protein in the $E B W_{;} N U T_{1}$ and $N U T_{2}$ are the effects of energy intake on growth (Oltjen et al., 1986; Oltjen et al., 2000), reported in equations 4 and 5 :

$$
N U T_{1}=-0.70+1.70 P
$$

and

$N U T_{2}=083+\frac{020 P}{015+P^{\prime}}$

where 
Table 2 - Summary descriptive analysis [mean, standard deviation (SD), minimum (Min) and maximum (Max)] of the model input variables for 14 crossbred bulls.

\begin{tabular}{|c|c|c|c|c|c|}
\hline \multirow{2}{*}{$\begin{array}{l}\text { Previous } \\
\text { weaning system }\end{array}$} & \multicolumn{5}{|c|}{ Measurements after experimental weaning } \\
\hline & $\begin{array}{c}\text { Descriptive } \\
\text { measures }\end{array}$ & Mean & SD & Min & Max \\
\hline & $\mathrm{BW}_{\mathrm{i}}^{3}, \mathrm{~kg}$ & 320.80 & 44.99 & 268.00 & 388.00 \\
\hline & $\mathrm{FP}^{4}, \mathrm{~d}$ & 132.60 & 32.19 & 75.00 & 147.00 \\
\hline & $\mathrm{DMl}^{5}, \mathrm{~kg} \mathrm{DMl} \mathrm{d}^{-1}$ & 8.69 & 1.10 & 7.67 & 10.14 \\
\hline & $\mathrm{BWj}_{\mathrm{f}}^{6}, \mathrm{~kg}$ & 483.60 & 52.65 & 428.00 & 568.00 \\
\hline \multirow[t]{10}{*}{$\mathrm{PS}^{1}$} & $\mathrm{BWz} z_{\mathrm{i}}^{7}, \mathrm{~kg}$ & 283.80 & 39.70 & 237.00 & 343.00 \\
\hline & $\mathrm{BWz}_{\mathrm{f}}^{8}, \mathrm{~kg}$ & 436.20 & 51.32 & 378.00 & 518.00 \\
\hline & PROT_BWz ${ }_{i}^{9}, \mathrm{~kg}$ & 50.10 & 7.02 & 41.90 & 60.60 \\
\hline & FAT_BWzi10 ${ }^{10}, \mathrm{~kg}$ & 38.92 & 5.47 & 32.50 & 47.10 \\
\hline & PROT_BWz $z_{f}^{11}, \mathrm{~kg}$ & 75.12 & 8.60 & 64.30 & 88.00 \\
\hline & FAT_BWz $\mathrm{z}_{\mathrm{f}}^{12}, \mathrm{~kg}$ & 75.10 & 12.95 & 67.50 & 98.10 \\
\hline & $\mathrm{BW}_{\mathrm{i}}, \mathrm{kg}$ & 329.00 & 30.75 & 270.00 & 366.00 \\
\hline & $F P, d$ & 108.55 & 31.51 & 75.00 & 147.00 \\
\hline & DMl, kg DMl d-1 & 8.81 & 0.80 & 7.52 & 9.78 \\
\hline & $B W \mathrm{j}_{\mathrm{f}}, \mathrm{kg}$ & 492.55 & 28.11 & 445.00 & 544.00 \\
\hline \multirow[t]{6}{*}{$\mathrm{CS}^{2}$} & $B W z_{i}, \mathrm{~kg}$ & 290.67 & 27.02 & 239.00 & 323.00 \\
\hline & $B W z_{f}, k g$ & 442.44 & 27.83 & 395.00 & 488.00 \\
\hline & PROT_BWz, kg & 51.01 & 4.71 & 42.20 & 57.20 \\
\hline & FAT_BWzi, kg & 42.85 & 5.67 & 32.80 & 51.00 \\
\hline & PROT_BWz & 75.81 & 4.69 & 67.90 & 83.90 \\
\hline & FAT_BWz $z_{f}, \mathrm{~kg}$ & 78.90 & 6.16 & 69.00 & 85.70 \\
\hline
\end{tabular}

IPS: Pasture System ( $n=5$ RCN); ${ }^{2}$ CS: Confined System $(n=5$ RCN; $n=$ 4 RN); ${ }^{3} B W_{\text {: }}$ initial body weight, kg; ${ }^{4}$ P: feedlot period, d; ${ }^{5} \mathrm{DMl}$ : dry matter intake, $\mathrm{kg} \mathrm{DMI} \mathrm{d}^{-1}$; ${ }^{6} \mathrm{BWj}$ : final shrunk body weight, $\mathrm{kg}$; ${ }^{7} \mathrm{BWz}$ : initial empty body weight, kg; ${ }^{8} \mathrm{BWz}$ : final empty body weight, $\mathrm{kg}$; ${ }^{9} \mathrm{PROT} \mathrm{BWz}$ : initial protein

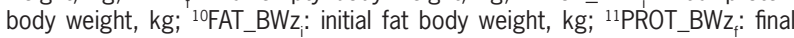
protein body weight, kg; ${ }^{12} \mathrm{FAT} \_\mathrm{BWz}$ : final fat body weight, $\mathrm{kg}$.

$$
P=\frac{M E I}{M E I_{\text {norm }}}
$$

is the ratio between the observed metabolizable energy intake (MEI, Mcal $\mathrm{d}^{-1}$ ) and the metabolizable energy intake reference $\left(M E I_{\text {norm }} \mathrm{Mcal} \mathrm{d}^{-1}\right)$,

$$
M E I_{\text {norm }}=[0.438-0.2615(E B W / M E B W)] \times E B W^{0.73},
$$

where $M E B W$ is the mature $E B W(600 \mathrm{~kg}$ for females and $900 \mathrm{~kg}$ for intact males).

The fat deposition rate is calculated by the ratio of the amount of residual energy and the average energy value of lipids, according to eq. (3), where FAT is the fat mass; EProt and Efat are the energy concentrations of protein and fat, respectively; $N E_{m}$ and $N E_{g}$ are net energy for maintenance and gain contents of the feed, respectively; and $M E_{M A I N T}$ is the metabolizable energy requirements for maintenance

$M E_{\text {MAINT }}=\left(\right.$ Mcal d $\left.^{-1}\right)=\alpha(E B W)^{0.75}$,

where $\alpha$ is the parameter to be estimated and represents the maintenance requirement of animals and $E B W$ can be estimated as

$$
E B W=F A T+\frac{P R O T}{0.2201}
$$

The parameters of interest in the DGM are $k_{1}, k_{2}$ $k_{3}, D N A_{\text {max }}$ and $\alpha$ (Eq. 1, 2 and 3). However, $k_{2}$ and $k_{3}$ are highly correlated, thus, it is not feasible to adjust the two parameters simultaneously. An alternative mentioned in the literature (Oltjen et al., 1986; Sainz et al., 2006) was to keep the value of $k_{2}$ at 0.0461 .

The gain composition and the dilution of maintenance requirements are two predominant processes to explain growth and food conversion efficiency into body tissues. The mechanistic process from the DGM allows the biological understanding of the growth process in detail through the evaluation of changes in underlying growth parameter $\left(k_{1}\right.$ and $\left.\alpha\right)$. Furthermore, the DGM enables the evaluation of trajectories of DNA mass and fat and protein tissue pools over time.

\section{Computational statistics}

A multivariate analysis of covariance (ANCOVA) was carried out to check for differences between the means of treatments and to cluster the treatments that were not significantly different. The parameters used to perform the multivariate analysis of covariance were individually fitted, $k_{1}$ and $\alpha$ by DGM, simultaneously. The statistical model for this analysis was:

$y_{i j k l p}=\mu+\alpha_{i p}+\beta j p+\gamma_{k p}+(\beta \times \gamma)_{j k p}+\rho_{i j k l p}+\varepsilon_{i j k l p}$

where $i=1, \ldots, b$ is the $i^{\text {th }}$ index of the breeds $(\mathrm{RCN}$ and $\mathrm{RN}) ; j=1, \ldots, s$ is the $j^{\text {th }}$ index of the systems (PS and CS); $k=1, \ldots, g$ is the $k^{\text {th }}$ index of the gender $(\mathrm{F}$ and $\mathrm{M}) ; l$ are replicates of each treatment (unbalanced experiment); $p$ $=1, \ldots, v$ is the $p^{\text {th }}$ index of the response variables (DNA accretion rate and energy requirement for maintenance); $y_{i j k l p}$ is the multivariate vector of observations of $p^{\text {th }}$ variable under the effe $\epsilon$ of $i^{\text {th }}$ breed, $j^{\text {th }}$ system, $k^{\text {th }}$ gender and $l^{\text {th }}$ repetition; $\mu$ is the general multivariate vector of constants inherent for all observations; $\alpha_{i p}$ is the multivariate vector of effects of the $i^{\text {th }}$ breed in $p^{\text {th }}$ variable; $\beta_{j p}$ is the multir ariate vector of effects of the $j^{\text {th }}$ system in $p^{\text {th }}$ variable; $\gamma_{k p}$ is the multivariate vector of effects of the $k^{\text {th }}$ gender in $p^{\text {th }}$ variable; $(\beta \times \gamma)_{j k p}$ is the multivariate vector of interaction effects between $j^{\text {th }}$ system and $k^{\text {th }}$ gender in $p^{\text {th }}$ variable; $\rho_{i j k l p}$ is the covariate (multivariate vector of effects from initial weights associated with observations $\left.y_{i j k l p}\right)_{;}$and $\varepsilon_{i j k l p}$ is the multivariate vector of errors associated with observations $y_{i j k l p}\left(\varepsilon_{i j k l p} \sim N_{2}(0, \Sigma)\right)$.

The multivariate ANCOVA showed no significant difference in mean vectors in relation to the breeds (data not reported). Nonparametric bootstrap resampling was run taking into account the following groups: females PS, females CS, males PS and males CS /reported in Tables 1 and 2). We performed 300 resampling nonparametric bootstraps for each group and determined the confidence interval of Biased Corrected Percentile Bootstrap (BCPB, Efron, 1979; Efron, 1981). 
The DGM was implemented in the R software (Development Core Team, version 3.1.0, 2014) and the function ode() of the deSolve package (Soetaert et al., 2010) for numerical solution of initial first-order problems was used. The solution was achieved using the lsoda integration method with absolute and relative error tolerances of $10^{-6}$.

Parameter values were determined using the downhill simplex optimization algorithm described by Nelder and Mead (1965) to minimize the residuals sum of squares. The residual sum of squares of the DGM was calculated in Eq. (11):

$\operatorname{Res}=\sum_{t=1}^{n} \sum_{u=1}^{m}\left(\frac{\hat{y}_{t u}-y_{t u}}{\sigma_{u}}\right)^{2}$

where $t=1,2, \ldots, n ; u=1, \ldots, m ; n$ is the number of animals and $m$ is the number of response variables, namely the protein mass and fat mass endpoint; Res is the residual sum of squares of all observations of the sample; $\hat{y}_{t u}$ and $y_{t u}$ are the predicted and observed values, respectively, of the $t^{\text {th }}$ individual in the $u^{\text {th }}$ variable of the DGM; and $\sigma$ is the standard deviation of the $u^{\text {th }}$ variable of the DGM. The standard deviation was used as a weighting factor for terms to become dimensionless, so it is important for different model variables that have different units and magnitudes. The function optim() and "stats" package from the $\mathrm{R}$ statiscal software ( $\mathrm{R}$ Core Team, 2014) was used to minimize Eq. (11).

The Nelder-Mead method optimizes nonlinear and multidimensional models requiring only an objective function without the need to be derived to find a solution (Press et al., 1990). The method uses an initial simplex [a set of vectors (points) in an M-dimensional space], where each vertex represents a possible solution. The number of simplex vertices is equal to the number of parameters to be fitted plus one. The scaling coefficients of the Nelder-Mead method for the reflection factor $(\beta)$, the contraction factor $(\lambda)$ and expansion factor $(\gamma)$ received values suggested by Press et al. (1990), i.e., 1.0, 0.5 and 2.0, respectively. The tolerance limit was $10^{-8}$ and the maximum number of interactions was 500 .

\section{Model evaluation}

In this section, we present several techniques for mathematical comparison of the models. These techniques are necessary to support decisions and to demonstrate the success of a model, presenting evidence to promote their acceptance and use for certain purposes. All predictions obtained through the model fit can be rewritten in the form of a simple linear regression, represented by the observed and predicted values according to the Eq.

$y=\beta_{0}+\beta_{1} x$

where $x$ is the predicted values; $y$ is the observed values; $\beta_{0}$ and $\beta_{1}$ are intercept and slope, respectively.
The regression was evaluated according to the following statistical hypothesis:

$\mathrm{H}_{0}: \beta_{0}=0$ and $\mathrm{H}_{0}: \beta_{1}=1$ and $\mathrm{H}_{\mathrm{a}}:$ not $\mathrm{H}_{0}$

If the null hypotheses were not rejected, it was concluded that the equations accurately estimated the observed values. The slope and the intercept were evaluated separately to identify specific problems of fitting. For all comparisons, 0.05 was established as the critical level of probability for type I error. The parameters $\beta_{0}$ and $\beta_{1}$ were evaluated separately and simultaneously to assess whether the bias was represented by a constant (evaluated by the intercept difference of parametric value zero) or by a tendency of percentage bias (evaluated by the slope deviation of parametric value 1).

Estimates were evaluated using the estimate value of the mean square error of the prediction (MSEP) and its components (Tedeschi, 2006):

$M S E P=\frac{\sum_{i=1}^{n}\left(x_{i}-y_{i}\right)^{2}}{n}$,

where $x$ is the predicted values; $y$ is the observed values; and $n$ is the number of observations.

The prediction of accuracy was determined by estimating the correlation concordance coefficient (CCC), or reproducibility index, as described by Tedeschi (2006). The CCC indicates models with good accuracy and precision (when close to 1.0) or models with problem of reproducibility (when close to 0.0). The smallest mean square error of prediction indicates the best model in the evaluation.

Other methods used for model evaluation were the Akaike Information Criterion (AIC) and the Bayesian Information Criterion (BIC), which were calculated, respectively, by Eqs. (15) and (16):

$$
\begin{aligned}
& A I C=\ln \left(\hat{\sigma}^{2}\right)+2 \frac{p}{n} \\
& \text { and } B I C=\ln \left(\hat{\sigma}^{2}\right)+2 \frac{p \ln (n)}{n}
\end{aligned}
$$

where $\hat{\sigma}^{2}$ is the variance of the estimated model; $p$ is the number of parameter settings of the estimated model and $n$ is the number of observations. The best performances of the model are provided by the lowest values of $A I C$ and BIC.

\section{Results and Discussion}

The results of the nonparametric bootstrap with the new parameterization of the model are shown in Table 3. The Kolmogorov-Smirnov (KS) normality test showed normal distribution for all parameters $(p>0.05)$, except for $k_{1}$ (females PS). This shows that the probability distribution is not the same, highlighting differences between groups like females PS and males CS (Figures 1A and B). The model parameter fitting and parameter correlation structures are important to characterize the behavior of 
Table 3 - Descriptive measures, Kolmogorov-Smirnov (KS) normality test ( $p$ value) and confidence intervals for the average Davis Growth Model (DGM) parameters with $95 \%$ of confidence.

\begin{tabular}{|c|c|c|c|c|c|c|c|c|c|}
\hline \multirow{2}{*}{ Gender } & \multirow{2}{*}{$\begin{array}{l}\text { Previous weaning } \\
\text { system }\end{array}$} & \multirow{2}{*}{$\begin{array}{c}\text { Fixed } \\
\text { Constants }\end{array}$} & \multirow{2}{*}{ Par. } & \multirow{2}{*}{$\begin{array}{l}\text { Original } \\
\text { sample }\end{array}$} & \multicolumn{2}{|c|}{ Bootstrap } & \multirow{2}{*}{$\begin{array}{l}p \text { value } \\
\text { KS }\end{array}$} & \multicolumn{2}{|c|}{$\mathrm{Cl} \mathrm{BCPB}^{3}$} \\
\hline & & & & & Mean & S.D. ${ }^{8}$ & & Lower limit & Upper limit \\
\hline \multirow{4}{*}{$\mathrm{F}^{1}$} & & $\left(k_{2}=0.0461\right)^{6}$ & $k_{1}$ & 0.0124 & 0.0167 & 0.0018 & 0.0460 & 0.0136 & 0.0187 \\
\hline & $\mathrm{PS}^{4}$ & $\begin{array}{l}\left(k_{3}=0.1430\right)^{6} \\
\left(D N A_{\max }=308\right)^{7}\end{array}$ & $\alpha$ & 0.1100 & 0.1082 & 0.0065 & 0.0894 & 0.0993 & 0.1185 \\
\hline & & $\left(k_{2}=0.0461\right)^{6}$ & $k_{1}$ & 0.0092 & 0.0119 & 0.0020 & 0.7173 & 0.0079 & 0.0160 \\
\hline & $\mathrm{CS}^{5}$ & $\begin{array}{l}\left(k_{3}=0.1430\right)^{6} \\
\left(D N A_{\text {max }}=308\right)^{7}\end{array}$ & $\alpha$ & 0.1216 & 0.1214 & 0.0022 & 0.9961 & 0.1171 & 0.1255 \\
\hline \multirow{4}{*}{$M^{2}$} & & $\left(k_{2}=0.0461\right)^{6}$ & $k_{1}$ & 0.0061 & 0.0067 & 0.0017 & 0.1882 & 0.0035 & 0.0095 \\
\hline & $\mathrm{PS}^{4}$ & $\begin{array}{l}\left(k_{3}=0.1430\right)^{6} \\
\left(D N A_{\text {max }}=462\right)^{7}\end{array}$ & $\alpha$ & 0.1360 & 0.1374 & 0.0024 & 0.1595 & 0.1311 & 0.1389 \\
\hline & & $\left(k_{2}=0.0461\right)^{6}$ & $k_{1}$ & 0.0084 & 0.0096 & 0.0005 & 0.5842 & 0.0086 & 0.0108 \\
\hline & $\mathrm{CS}^{5}$ & $\begin{array}{l}\left(k_{3}=0.1430\right)^{6} \\
\left(D N A_{\max }=462\right)^{7}\end{array}$ & $\alpha$ & 0.1199 & 0.1204 & 0.0031 & 0.2023 & 0.1140 & 0.1255 \\
\hline
\end{tabular}

${ }^{1}$ Females; ${ }^{2}$ Males; ${ }^{3}$ Confidence interval of Biased Corrected Percentile Bootstrap; ${ }^{4}$ Pasture System; ${ }^{5}$ Confined System; ${ }^{6}$ Fixed values based by Oltjen et al. (1986); ${ }^{7} D N A_{\max }$ was based on direct and linear proportion of mature weight of the breed and gender of these animals; ${ }^{8}$ Standard Deviation.

a system in response to multiple variations (climate, genotypes, nutritional diet, system, and other factors). The adjusted model for the four specific scenarios ensures greater predictability and can be a useful tool to adapt systems to higher profitability. The negative correlation between the rate constant for addition of DNA and the maintenance requirement energy of animal was found for intact males PS (Figure 2C). This correlation indicates that the animals with faster lean tissue deposition also have better performance because they tend to dilute the energy for maintenance with the greater proportion of energy intended for tissue deposition. The joint dispersion matrices of the nonparametric bootstrap estimates, Pearson correlation and frequency histograms for $k_{1}$ and $\alpha$, are shown in Figures 2A, B, C and D.

There was no difference between the PS and CS systems within the female gender, considering the parameters $k_{1}$ and $\alpha$ simultaneously. There was no difference in the CS level change for PS level, regarding the gender factor, in weight gain $\left(k_{1}\right)$. This was an expected result, since PS animals have a similar growth rate during the compensatory gain compared to CS animals (Table 3). The results show significant differences, about $\alpha$, between males PS and males CS, with the largest maintenance of energy average for males PS (Table 3). This behavior in male animals was expected because animals from CS were slaughtered in a shorter time during the feedlot in relation to animals from PS (Table 2).

The reparametrized model in this study (Figures 3A, $\mathrm{B}, \mathrm{C}$ and D) improved predictions of the original parameters (Bos Taurus reference bull, Figures 3E, F, G and H). The bias of the proposed new parameters calculated considering average protein and fat concentration are smaller than the bias considering calculated average predictions of protein and fat concentration using the original calibration of the model by Oltjen et al. (1986), respectively (Table 4). The evaluation of the model (Table 5) using the criteria MSEP, $\mathrm{CCC}$, intercept, slope, AIC, and BIC corroborate the
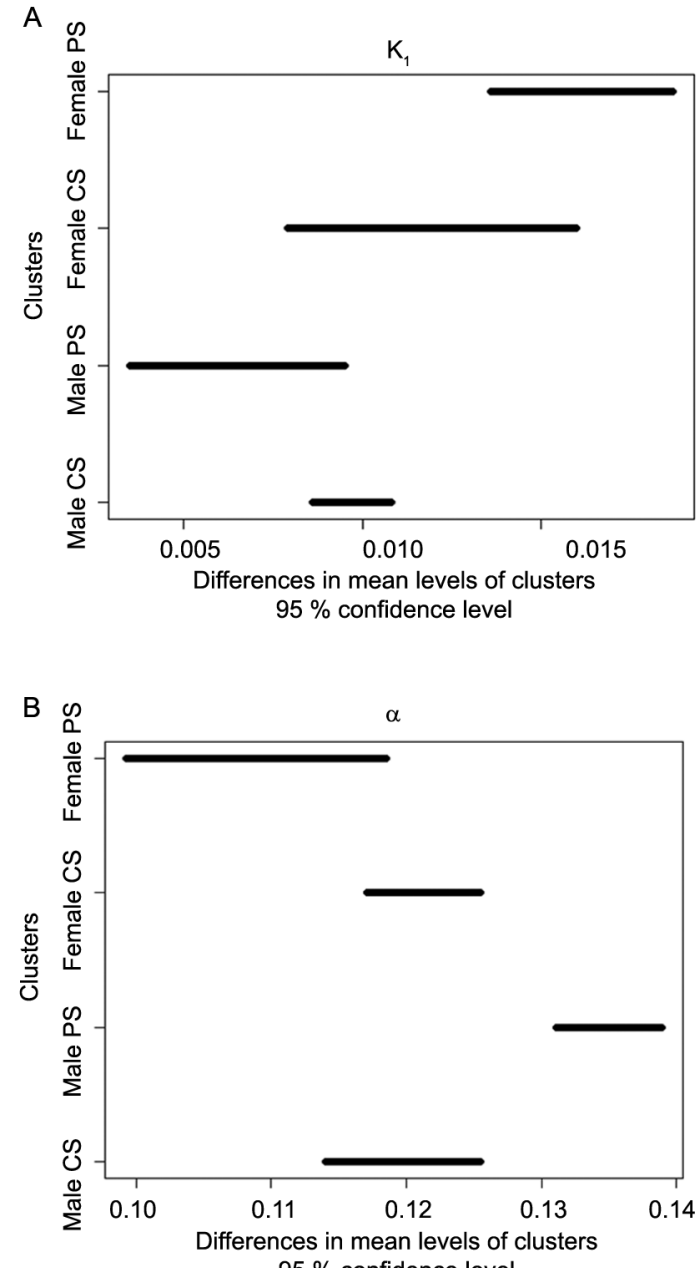

$95 \%$ confidence level

Figure 1 - Confidence intervals of Biased Corrected Percentile Bootstrap for the mean Davis Growth Model parameters with $95 \%$ of confidence, A) parameter $\mathrm{k} 1$ and B) parameter $\alpha$ (PS: Pasture System; CS: Confined System). 
A

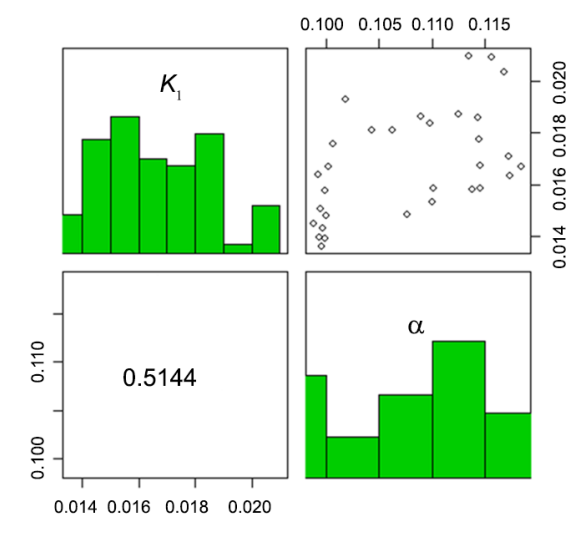

C

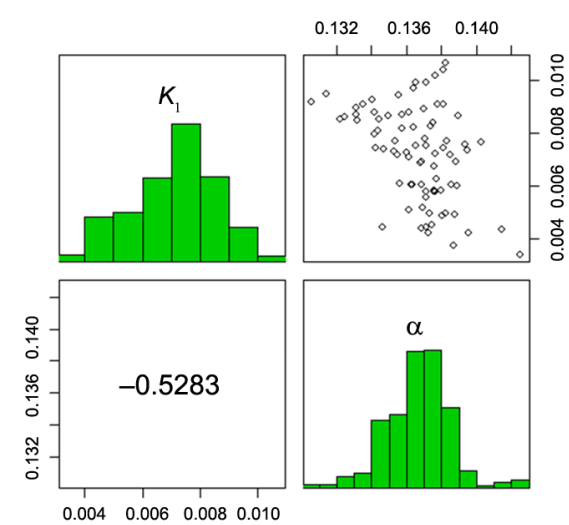

B

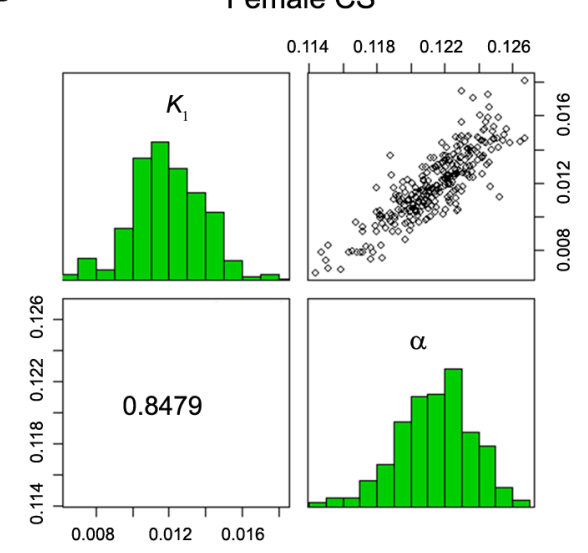

D

Male CS

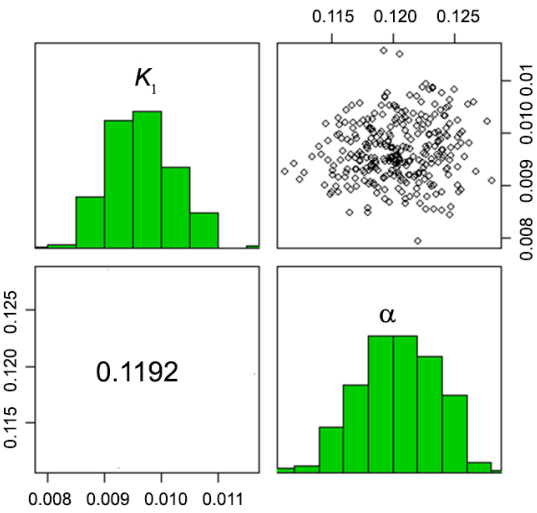

Figure 2 - Joint dispersion matrixes of the nonparametric bootstrap estimates, the Pearson correlation, and frequency histograms for k1 and $\alpha$ to the Davis Growth Model A) Female PS (Pasture System); B) Female CS (Confined System); C) Male PS; D) Male CS.

Table 4 - Comparison of average predictions of protein and fat between the new calibrations proposed in this study and calibrations using the original values of Oltjen et al. (1986).

\begin{tabular}{|c|c|c|c|c|c|c|}
\hline \multirow[b]{2}{*}{ Clusters } & \multirow[b]{2}{*}{ Variables } & \multirow[b]{2}{*}{ Observed } & \multicolumn{2}{|c|}{ New calibrations ${ }^{1}$} & \multicolumn{2}{|c|}{ Original parameters² } \\
\hline & & & Predicted & Bias & Predicted & Bias \\
\hline Females & Protein $\left(\mathrm{kg} \mathrm{d}^{-1}\right)$ & 58.0500 & 57.9920 & 0.0579 & 53.8236 & 4.2264 \\
\hline $\mathrm{PS}^{3}$ & Fat $\left(\mathrm{kg} \mathrm{d}^{-1}\right)$ & 74.4000 & 73.4140 & 0.9859 & 87.3991 & -12.9991 \\
\hline Females & Protein $\left(\mathrm{kg} \mathrm{d}^{-1}\right)$ & 54.8777 & 54.9139 & -0.0361 & 51.9247 & 2.9669 \\
\hline $\mathrm{CS}^{4}$ & Fat $\left(\mathrm{kg} \mathrm{d}^{-1}\right)$ & 69.3700 & 68.8142 & 0.5635 & 82.7235 & -13.3535 \\
\hline Males & Protein $\left(\mathrm{kg} \mathrm{d}^{-1}\right)$ & 75.1200 & 74.4028 & 0.7171 & 53.8236 & 21.2964 \\
\hline $\mathrm{PS}^{3}$ & Fat $\left(\mathrm{kg} \mathrm{d}^{-1}\right)$ & 75.1000 & 74.9045 & 0.1954 & 87.3991 & -12.2991 \\
\hline Males & Protein $\left(\mathrm{kg} \mathrm{d}^{-1}\right)$ & 75.8111 & 75.5887 & 0.2223 & 67.8307 & 7.9804 \\
\hline $\mathrm{CS}^{4}$ & Fat $\left(\mathrm{kg} \mathrm{d}^{-1}\right)$ & 78.9000 & 79.4407 & -0.5407 & 105.9546 & -27.0546 \\
\hline
\end{tabular}

${ }^{1}$ Parameter fit in the current study; ${ }^{2}$ Based on parameters $\left(k_{1}, \alpha\right)$ calculated in the Oltjen et al. (2000) study; ${ }^{3}$ Pasture System; ${ }^{4}$ Confined System.

results shown in Figures $3 \mathrm{~A}, \mathrm{~B}, \mathrm{C}, \mathrm{D}, \mathrm{E}, \mathrm{F}, \mathrm{G}$, and $\mathrm{H}$, indicating improvement in performance of the model with new estimates of the current study compared to the original estimates by Oltjen et al. (1986). Therefore, this fitted model was provisionally accepted for growth simulation of Nellore (Bos indicus) and Nellore crossbred animals, although pending further evaluations with an independent dataset.
In this study, $k_{1}$ and $\alpha$ values were higher than the original DGM parameters (Oltjen et al., 1986). In the study conducted by Oltjen et al. (1986), $k_{1}$ had a minimum increase of $156 \%$ and the maximum of 389 $\%$ compared to the original values $\left(k_{1}=0.00429\right.$, Table $6)$, while $\alpha$ had a minimum increase of $126 \%$ and the maximum of $160 \%$ compared to the original values ( $\alpha$ $=0.086$, Table 6). Previous study involving reparameter- 

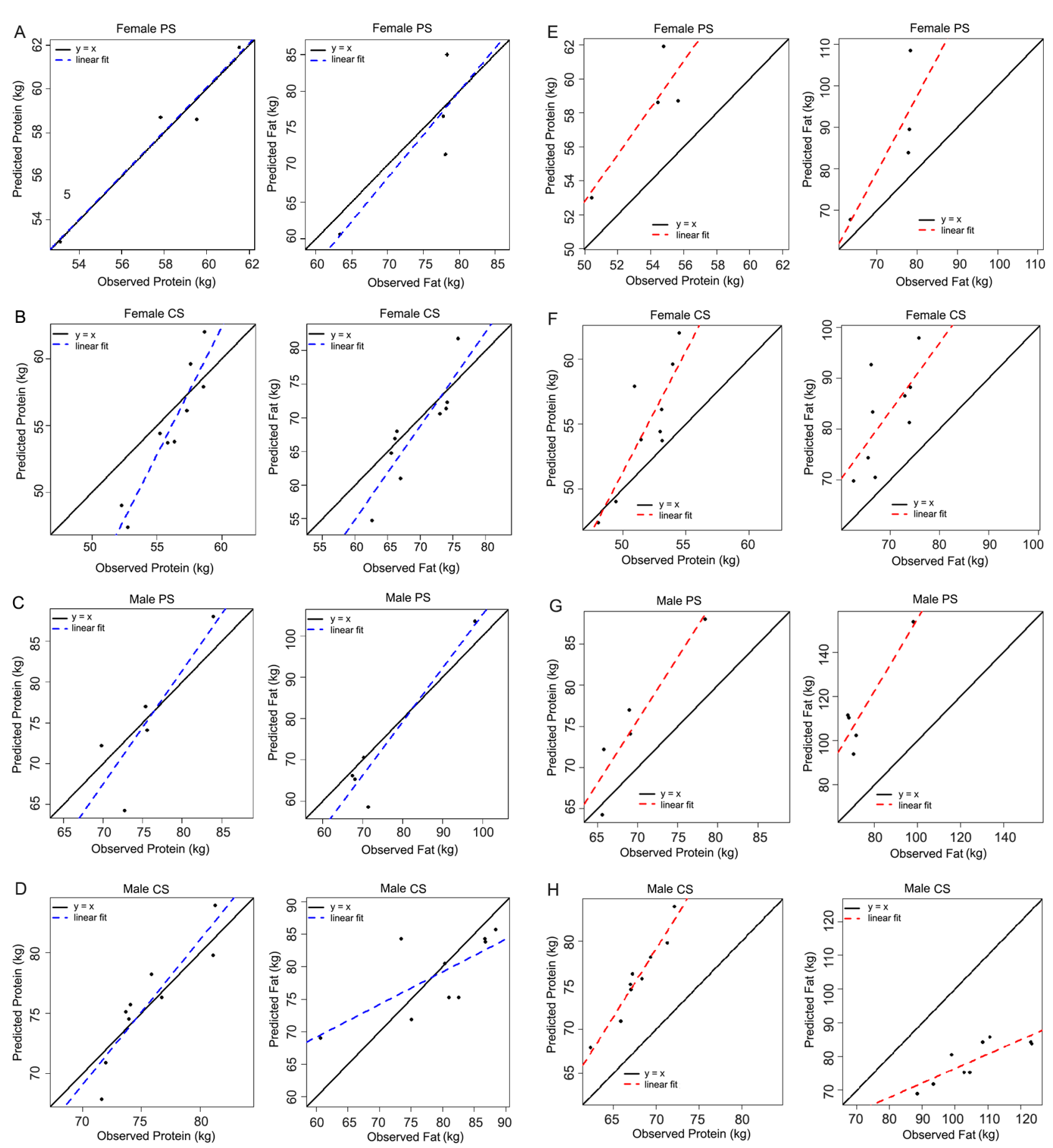

Figure 3 - Observed and predicted values for protein and fat. (A - D) modified parameters; $(E-H)$ original parameters (Bos Taurus reference bull); PS: Pasture System; CS: Confined System.

ization of the model with Nellore bulls by Sainz et al. (2006) estimated rates for $k_{1}, k_{3}$ and $\alpha\left(k_{1}=0.00304, k_{3}\right.$ $=0.1300$, and $\alpha=0.0768)$, keeping fixed $k_{2}(0.0479)$ and $D N A_{\max }(462 \mathrm{~g})$. Compared to Sainz et al. (2006), $k_{1}$ had a minimum increase of $220 \%$ and the maximum of $549 \%$; $\alpha$ had a minimum increase of $141 \%$ and the maximum of $178 \%$ (Table 7). Breeds and genetic improvement are the possible causes of parameter changes.

There are two hypotheses to explain the higher values of $k_{1}$ and $\alpha$ compared to previous research: 1) heterosis (maximum for $\mathrm{RN}$ and lower for $\mathrm{RCN}$ ) increased the value of the parameters when compared with Zebu genotype (i.e., 
Biase et al.

Dynamic system in Brazilian livestock

Table 5 - Evaluation of Davis Growth Model (DGM) with the estimates obtained by bootstrap analysis of the current study and evaluation using the original estimates of model Oltjen et al. (1986).

\begin{tabular}{|c|c|c|c|c|c|}
\hline \multirow{2}{*}{ Scenarios } & \multirow{2}{*}{ Statistics } & \multicolumn{2}{|c|}{ (New calibrations) Bootstrap ${ }^{1}$} & \multicolumn{2}{|c|}{ Original parameters ${ }^{2}$} \\
\hline & & Protein & Fat & Protein & Fat \\
\hline & MSEP3 & 2.1369 & 24.8920 & 20.9818 & 274.8000 \\
\hline & $\mathrm{CCC}^{4}$ & 0.9539 & 0.9384 & 0.3481 & 0.3495 \\
\hline Females & $p$ value $^{5}$ & 0.9270 & 0.8352 & 0.6450 & 0.1160 \\
\hline Pasture & $p$ value $^{6}$ & 0.8283 & 0.2753 & 0.5678 & 0.0725 \\
\hline \multirow[t]{5}{*}{ System } & $p$ value $^{7}$ & 0.7576 & 0.2889 & 0.2157 & 0.1021 \\
\hline & $\mathrm{AlC}^{8}$ & 16.1524 & 16.1524 & 21.0760 & 21.0758 \\
\hline & $\mathrm{BIC}^{9}$ & 14.3113 & 25.2490 & 19.2347 & 26.2856 \\
\hline & MSEP $^{3}$ & 7.6008 & 17.0037 & 17.3109 & 228.6716 \\
\hline & $\mathrm{CCC}^{4}$ & 0.7053 & 0.7720 & 0.4810 & 0.2070 \\
\hline Females & $p$ value $^{5}$ & 0.0086 & 0.0046 & 0.1120 & 0.0079 \\
\hline Confined & $p$ value $^{6}$ & 0.0095 & 0.0056 & 0.0925 & 0.0018 \\
\hline \multirow[t]{5}{*}{ System } & $p$ value $^{7}$ & 0.0249 & 0.0199 & 0.0335 & 0.0000 \\
\hline & $\mathrm{AlC}^{8}$ & 38.7718 & 38.7718 & 47.0016 & 47.0016 \\
\hline & $\mathrm{BIC}^{9}$ & 39.3634 & 45.9810 & 47.5933 & 54.1773 \\
\hline & MSEP $^{3}$ & 19.6221 & 40.9915 & 44.7486 & 1668.4700 \\
\hline & $\mathrm{CCC}^{4}$ & 0.7600 & 0.8970 & 0.6340 & 0.2440 \\
\hline Males & $p$ value ${ }^{5}$ & 0.4784 & 0.0878 & 0.2823 & 0.3543 \\
\hline Pasture & $p$ value $^{6}$ & 0.4822 & 0.1030 & 0.2215 & 0.0328 \\
\hline \multirow[t]{5}{*}{ System } & $p$ value $^{7}$ & 0.8298 & 0.2844 & 0.1353 & 0.0031 \\
\hline & $\mathrm{AlC}^{8}$ & 34.0756 & 32.9613 & 30.5307 & 35.5494 \\
\hline & $\mathrm{BIC}^{9}$ & 32.9039 & 31.7896 & 29.3590 & 34.3778 \\
\hline & MSEP 3 & 3.8026 & 33.8657 & 67.2039 & 784.8868 \\
\hline & $\mathrm{CCC}^{4}$ & 0.8170 & 0.9398 & 0.2830 & 0.1340 \\
\hline Males & $p$ value $^{5}$ & 0.5182 & 0.0354 & 0.0239 & 0.0224 \\
\hline Confined & $p$ value $^{6}$ & 0.5691 & 0.0304 & 0.0080 & 0.0011 \\
\hline \multirow{3}{*}{ System } & $p$ value $^{7}$ & 0.2907 & 0.1094 & 0.0000 & 0.0000 \\
\hline & $\mathrm{AlC}^{8}$ & 42.2798 & 56.9118 & 33.2404 & 52.8159 \\
\hline & $\mathrm{BIC}^{9}$ & 42.8714 & 57.5034 & 33.8321 & 53.4075 \\
\hline
\end{tabular}

${ }^{1}$ Parameter fit in the current study; ${ }^{2}$ Based on parameters fit $\left(k_{1}, \alpha\right)$ calculated in the Oltjen et al. (1986) study; ${ }^{3}$ Mean square error of prediction (smaller is better); ${ }^{4}$ Concordance Correlation Coefficient (closer to 1 is better); $p$ value: $\left(H_{0}: \beta_{0}=0\right) ; p$ value ${ }^{6}:\left(H_{0}: \beta_{1}=1\right) ; p$ value $:\left(H_{0}: \beta_{0}=0\right.$ and $\left.\beta_{1}=1\right) ;{ }^{8}$ Akaike Information Criterion (smaller is better); ${ }^{9}$ Bayesian Information Criterion (smaller is better).

Table 6 - Percentage of change of the current values of the parameters in relation to the original values of Oltjen et al. (1986).

\begin{tabular}{|c|c|c|c|c|c|}
\hline \multicolumn{5}{|c|}{ Zebu crossbred ${ }^{1}$} & \multirow{2}{*}{$\begin{array}{c}\begin{array}{c}\text { British } \\
\left.\text { (Bos taurus }{ }^{2}\right) \\
\text { Steer }\end{array} \\
\end{array}$} \\
\hline $\begin{array}{l}\text { Parameter } \\
\text { fit }\end{array}$ & $\begin{array}{c}\text { Females } \\
\text { PS }^{3}\end{array}$ & $\begin{array}{c}\text { Females } \\
\mathrm{CS}^{4}\end{array}$ & $\begin{array}{l}\text { Males } \\
\text { PS }^{3}\end{array}$ & $\begin{array}{c}\text { Males } \\
\mathrm{CS}^{4}\end{array}$ & \\
\hline $\mathrm{k}_{1}$ & 0.0167 & 0.0119 & 0.0067 & 0.0096 & 0.00429 \\
\hline$\alpha$ & 0.1082 & 0.1214 & 0.1374 & 0.1204 & 0.0860 \\
\hline$\%$ of & $k_{1}(389 \%)$ & $\varepsilon_{1}(214 \%)$ & $\varepsilon_{1}(156 \%)$ & $k_{1}(223 \%)$ & - \\
\hline
\end{tabular}
change $\quad \alpha(126 \%) \quad \alpha(141 \%) \quad \alpha(160 \%) \quad \alpha(140 \%)$

${ }^{1}$ Parameter fit in the current study; ${ }^{2}$ Based on parameters $\left(k_{1}, \alpha\right)$ calculated in the Oltjen et al. (1986) study; ${ }^{3}$ Pasture System; ${ }^{4}$ Confined System.

Nellore used by Sainz et al., 2006); and 2) the experiment was conducted with animals from herds selected by Embrapa in 2010, three to seven generations after the Sainz et al. (2006) and Oltjen et al. (1986) studies. These cases reinforce both the improvement through crossing and selection, as well as genetic progress associated with increased $k_{1}$ and $\alpha$. In Brazil as in other countries, weight is the main selection criteria with moderate to high genetic
Table 7 - Percentage of change of the current values of the parameters in relation to the original values of Sainz et al. (2006).

\begin{tabular}{|c|c|c|c|c|c|}
\hline \multicolumn{5}{|c|}{ Zebu crossbred ${ }^{1}$} & \multirow{2}{*}{$\begin{array}{c}\begin{array}{c}\text { Nellore } \\
\left(\text { Bos indicus }{ }^{2}\right)\end{array} \\
\text { Bulls }\end{array}$} \\
\hline $\begin{array}{l}\text { Parameter } \\
\text { fit }\end{array}$ & $\begin{array}{c}\text { Females } \\
\mathrm{PS}^{3}\end{array}$ & $\begin{array}{c}\text { Females } \\
\mathrm{CS}^{4}\end{array}$ & $\begin{array}{c}\text { Males } \\
\text { PS }^{3}\end{array}$ & $\begin{array}{c}\text { Males } \\
\text { CS }^{4}\end{array}$ & \\
\hline $\mathrm{k}_{1}$ & 0.0167 & 0.0119 & 0.0067 & 0.0096 & 0.00304 \\
\hline$\alpha$ & 0.1082 & 0.1214 & 0.1374 & 0.1204 & 0.0768 \\
\hline $\begin{array}{l}\% \text { of } \\
\text { change }\end{array}$ & \multicolumn{4}{|c|}{$k_{1}(549 \%) k_{1}(391 \%) k_{1}(220 \%) k_{1}(315 \%)$} & - \\
\hline
\end{tabular}
the Sainz et al. (2006) study; ${ }^{3}$ Pasture System; ${ }^{4}$ Confined System.

correlation with growth curve parameters (Meyer, 1995; Mignon-Grasteau, 1999), and potentially with $k_{1}$ and $\alpha$.

\section{Conclusions}

The parameters showed normal probability distribution for most scenarios. Confidence intervals produced through bootstrap inferred that model parameters 
differ from the original values determined by Oltjen et al. (1986). Breeds and genetic improvement are the possible causes of parameter changes. Intact male animals of the pasture system showed negative correlation between the protein deposition rate and requirement for energy maintenance, indicating that the animals with faster lean tissue deposition also have better performance because they tend to dilute the energy cost for maintenance, with a greater proportion of energy used for tissue deposition. We highlight that the generalization of this finding demands studies with larger populations. The new estimates of parameter values, instead of the originals, can be used for predictive purposes for crossbred cattle.

\section{Acknowledgements}

The authors express their thanks to Coordination for the Improvement of Higher Level Personnel (CAPES) and Brazilian Agricultural Research Corporation (Embrapa) for providing scholarship and University of São Paulo/ESALQ academic formation by the first author, the Embrapa Beef Cattle, Animal Nutrition and Growth Laboratory - USP/ESALQ and São Paulo State Foundation for Research Support (FAPESP) for providing the data and grants, as well the Embrapa Eastern Amazon and Embrapa Agricultural Informatics by the scientific partnership group of the Pecus and AnimalChange network.

\section{References}

Albertini, T.Z.; Medeiros, S.R.; Torres Júnior, R.A.; Zocchi, S.S.; Oltjen, J.W.; Strathe, A.B.; Lanna, D.P.D. 2012. A methodological approach to estimate the lactation curve and net energy and protein requirements of beef cows using nonlinear mixedeffects modeling. Journal of Animal Science 90: 3867-3878.

Bonilha, S.F.M.; Tedeschi, L.O.; Packer, I.U.; Razook, A.G.; Nardon, R.F.; Figueiredo, L.A.; Alleoni, G.F. 2011. Chemical composition of whole body and carcass of Bos indicus and tropically adapted Bos Taurus breeds. Journal of Animal Science 89: 2859-2866.

Bhowmick, A.R.; Bhattacharya, S. 2014. A new growth curve model for biological growth: some inferential studies on the growth of Cirrhinus mrigala. Mathematical Biosciences 254: 28-41.

Chizzotti, M.L.; Tedeschi, L.O.; Valadares Filho, S.C. 2008. A metaanalysis of energy and protein requirements for maintenance and growth of Nellore cattle. Journal of Animal Science 86: 1588-1597.

Freetly, H.C.; Kuehn, L.A.; Cundiff , L.V. 2011. Growth curves of crossbred cows sired by Hereford, Angus, Belgian Blue, Brahman, Boran, and Tuli bulls, and the fraction of mature body weight and height at puberty. Journal of Animal Science 89: 2373-2379.

France, J.; Gill, M.; Thornley, J.H.M.; England, P. 1987. A model of nutrient utilization and body composition in beef cattle. Animal Production 44: 371-385.
Forni, S.; Piles, M.; Blasco, A.; Varona, L.; Oliveira, H.N.; Lôbo, R.B.; Albuquerque, L.G. 2009. Comparison of different nonlinear functions to describe Nelore cattle growth. Journal of Animal Science 87: 496-506.

Efron, B. 1979. Bootstrap methods: another look at the jackknife. The Annals of Statistics 7: 1-26.

Efron, B. 1981. Nonparametric standard errors and confidence intervals. Canadian Journal of Statistics 9: 139-172.

Hankins, O.G.; Howe, P.E. 1946. Estimation of the Composition of Beef Carcass Cuts. USDA, Washington, DC, USA. (Technical Bulletin, 26.).

Hoch, T.; Agabriel, J. 2004. A mechanistic dynamic model to estimate beef cattle growth and body composition. 1. Model description. Agricultural Systems 81: 1-15.

Marinho, K.N.S.; Freitas, A.R.; Falção, A.J.S.; Dias, F.E.F. 2013. Nonlinear models for fitting growth curves of Nellore cows reared in the Amazon Biome. Revista Brasileira de Zootecnia 42: 645-650.

Marcondes, M.I.; Chizzotti, M.L.; Valadares Filho, S.C.; Gionbelli, M.P.; Paulino, P.V.R.; Paulino, M.F. 2010a. Energy requirements of zebu beef cattle. p. 81-106. In: Valadares Filho, S.C.; Marcondes, M.I.; Chizzotti, M.L.; Paulino, P.V.R., eds. Nutrient requirements of zebu beef cattle BR-CORTE. 2ed. UFV, Viçosa, MG, Brazil.

Marcondes, M.I.; Chizzotti, M.L.; Valadares Filho, S.C.; Gionbelli, M.P.; Paulino, P.V.R.; Paulino, M.F. 2010b. Protein requirements of zebu beef cattle. p. 107-126. In: Valadares Filho, S.C.; Marcondes, M.I.; Chizzotti, M.L.; Paulino, P.V.R., eds. Nutrient requirements of zebu beef cattle BR-CORTE. 2ed. UFV, Viçosa, MG, Brazil.

Meyer, K. 1995. Estimates of genetic parameters for mature weight of Australian beef cows and its relationship to early growth and skeletal measures. Livestock Production Science 44: 125-137.

Mignon-Grasteau, S. 1999. Genetic parameters of growth curve parameters in male and female chickens. British Poultry Science 40: 44-51.

National Research Council [NRC]. 1996. Nutrient Requirements of Beef Cattle. 7ed. The National Academies Press, Washington, DC, USA. p. 234.

Nelder, J.A.; Mead, R. 1965. A simplex algorithm for function minimization. Computer Journal 7: 308-313.

Nesetrilová, H. 2005. Multiphasic growth models for cattle. Czech Journal of Animal Science 8: 347-354.

Oltjen, J.W.; Pleasants, A.B.; Soboleva, T.K.; Oddy, V.H. 2000. Second-generation dynamic cattle growth and composition models. p. 197-209. In: McNamara, J.P.; France, J.; Beever, D.E., eds. Modelling nutrient utilization in farm animals. CAB International, Wallingford, UK.

Oltjen, J.W.; Bywater, A.C.; Baldwin, R.L.; Garrett, W.N. 1986. Development of a dynamic model of beef cattle growth and composition. Journal of Animal Science 62: 86-97.

Paulino, P.V.R.; Fonseca, M.A.; Henriques, L.T.; Valadares Filho, S.C.; Detmann, E. 2010. Nutritional requirements of nellore cows and calves. p. 167-185. In: Valadares Filho, S.C.; Marcondes, M.I.; Chizzotti, M.L.; Paulino, P.V.R., eds. Nutrient requirements of zebu beef cattle BR-CORTE. 2ed. UFV, Viçosa, MG, Brazil. 
Press, W.H.; Flannery, B.P.; Teukolsky, S.A.; Vetterling, W.T. 1990. Numerical recipes in C: the art of scientific computing. Cambridge University Press, New York, NY, USA.

Reid, J.T.; Wellington, G.H.; Dunn, H.O. 1955. Some relationships among the major chemical components of the bovine body and their application to nutritional investigations. Journal of Dairy Science 38: 1344-1359.

Sainz, R.D.; Barioni, L.G.; Paulino, P.V.; Valadares Filho, S.C.; Oltjen, J.W. 2006. Growth patterns of Nellore vs British beef cattle breeds assessed using a dynamic, mechanistic model of cattle growth and composition. p. 160-170. In: Kebreab, E.; Dijkstra, J.; Bannink, A.; Gerrits, W.J.J.; France, J., eds. Nutrient digestion and utilization in farm animals: modeling approaches. CAB International, Wallingford, UK.

Soetaert, K.; Petzoldt, T.; Setzer, R.W. 2010. Solving differential equations in R: package deSolve. Journal of Statistical Software 33: 1-25.
Tedeschi, L.O. 2006. Assessment of the adequacy of mathematical models. Agricultural Sciences 89: 225-247.

Tedeschi, L.O.; Fox, D.G.; Guiroy, P.J. 2004. A decision support system to improve individual cattle management. 1. A mechanistic, dynamic model for animal growth. Agricultural Systems 79: 171-204.

Valente, E.E.L.; Paulino, M.F.; Detmann, E.; Valadares Filho, S.C.; Cardenas, J.E.G.; Dias, I.F.T. 2013. Requirement of energy and protein of beef cattle on tropical pasture. Acta Scientiarum 35: 417-424.

Williams, C.B.; Bennett, G.L. 1995. Application of a computer model to predict optimum slaughter end points for different biological types of feeder cattle. Journal of Animal Science 73: 2903-2915.

Williams, C.B.; Jenkins, T.G. 2003. A dynamic model of metabolizable energy utilization in growing and mature cattle. II. Metabolizable energy utilization for gain. Journal of Animal Science 81: 1382-1389. 